\title{
GEOLOGICAL MAPPING IN URBAN AREAS. A CASE STUDY FROM THE INNER CITY OF THESSALONIKI, GREECE
}

\author{
Zervopoulou A. ${ }^{1}$ and Pavlides S. ${ }^{1}$ \\ ${ }^{1}$ Aristotle University of Thessaloniki, Department of Geology, 54124, Thessaloniki, Greece, \\ annezervo@gmail.com, pavlides@geo.auth.gr
}

\begin{abstract}
The methodology of geological mapping in urban areas differs from the ordinary field research. An urban area has no outcrops, has a smooth surface, diverted water lines and covered geology. The data types commonly collected in urban areas are from few outcrops (if there are some), borehole records, geophysical prospecting data, geological maps, digital elevation models (DEM), shallow excavations, palaeoseismological trenches and publication archives. This research at subsurface of the city produces new thematic maps for the initial surface under the building area, the water network, the geology and finally the fault system. This paper demonstrates a methodology and provides a way to solve engineering geology problems in urban areas. Keywords: Neotectonics, active faults, boreholes, geology, DEM.
\end{abstract}

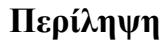

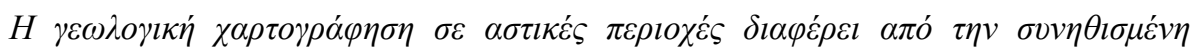

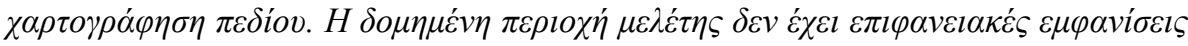

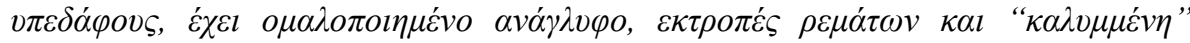

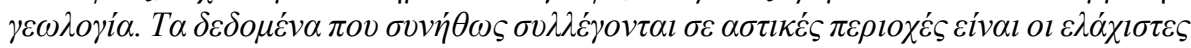

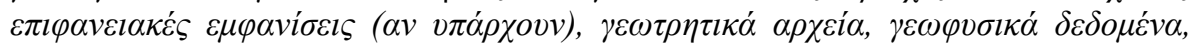

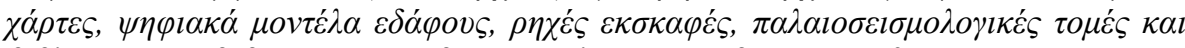

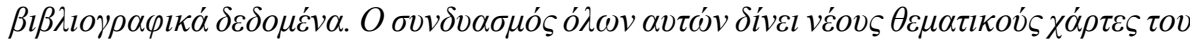

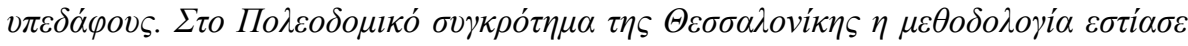

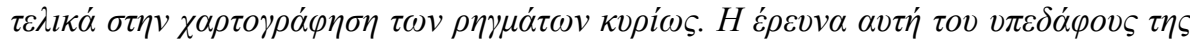

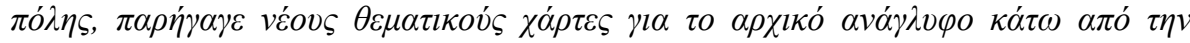

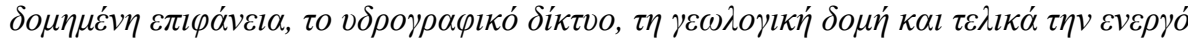

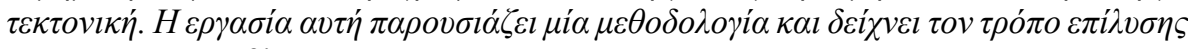

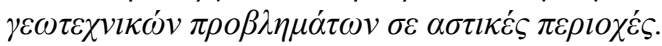

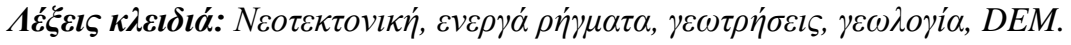

\section{Introduction}

To understand the geological environment and geotechnical conditions of an urban area a specialized methodology is required. The usual methodology for an "open" area includes initially surface mapping, and then geological crosssections. In urban areas the initial surface has been shaped due to the rapid growth, in a way that covers the needs of the inhabitants of a region. The land surfaces have been built and sharpen artificially, roads have been constructed, and the hydrographic networks have changed and shaped, while natural surface have been fragmented and degraded, hence the constructed landscape is "poor" for geological study. With all the constructions, the initial data that 
could provide the references for the tectonic regime have been lost (Chuang Xu et al., 2015). To study the subsoil geology data from excavations can be used at first, which are isolated and not mapped, and secondly from borehole data. Even those boreholes are shallow and serving the purposes which are made for. Only the water wells are deeper, but contain few useful geological data. Along with the drilling for creating geological profiles used geophysical data, which could provide geological evidence for deeper depths.

Geologists have a long history of working in cities alongside engineers (e.g. Legget, 1973), while the term Urban geology appeared by Alfors et al. (1973) for the master plan for California (Natural disasters, Geology, Land use, Urban plan) published by California Division of Mines and Geology (University of California Libraries). Similar publications and methodologies can be found in the Urban Geology series of the Geological Survey of Japan, in McCall et al. (1996), in lectures like "The contribution of urban geology to the development, regeneration and conservation of cities" (Culshaw and Price, 2011), as well as in special issues like Engineering Geology and the Environment: Marinos et al. (1996, 2001).

With 2D geological maps, digital elevation models (DEM) and archival publications such as old photographs and maps, new 3D models can be produced for an urban area, before its urbanization. New 2D geological maps for the underground geology can be produced, as well as 3D maps. With these maps, it is possible to track the tectonic structures. From these structures, the active faults, which can cause problems at the structured network of the city in a possible activation, can be separated. Finally, the geotectonically more vulnerable areas related to active tectonism, can be mapped.

This paper focused on the inner city of Thessaloniki, where have been produced the 3D models with more detail processing.

\section{The case study of Thessaloniki}

Thessaloniki is an old historical city in northern Greece (Figure 2), with continues urbanization since $315 \mathrm{BC}$. The city extends in $65 \mathrm{~km}^{2}$ at present days.

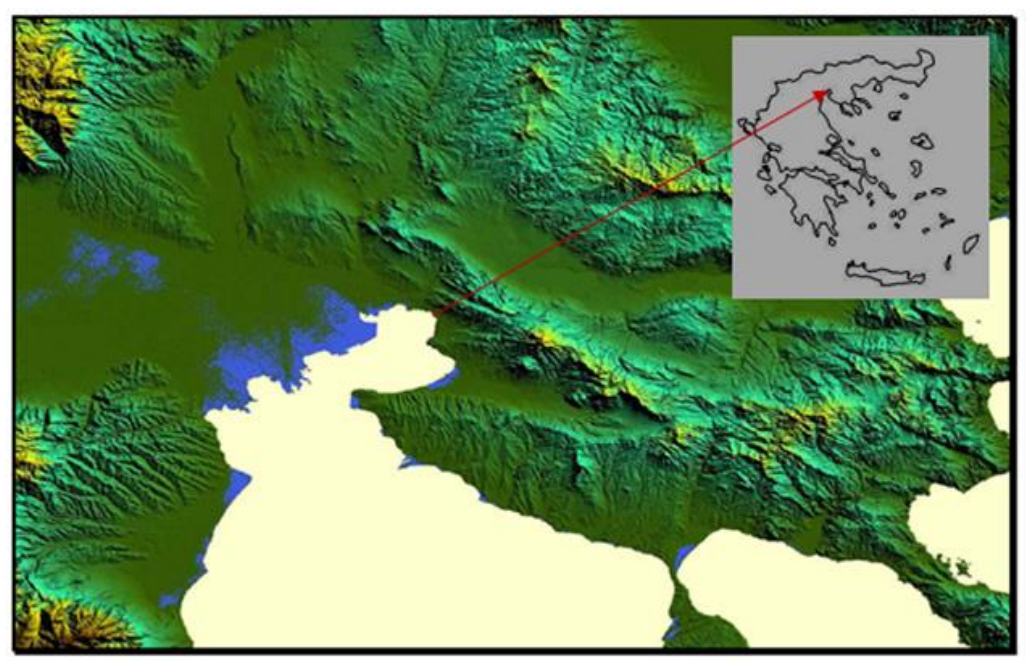

Figure 1 - 3D Digital Elevation Model (SRTM) of the Mecedonia, Greece and Thessaloniki.

For the original morphology, old topographic maps (1945) at the 1:5.000 and 1:50.000 scales have been used. Historical maps since 1784 such as old photographs and aerial photograph (1939), as well as archaeological and literature data were also used. From all those data, the hydrographic network of the area before the inhabitation, which is the natural stream courses in an area and is 
related to local geologic and geomorphologic features and history was composed. The main problem was the inability to map the original terrain in the walled ancient city, because of limited archaeological evidence.

\subsection{Water network - Initial surface}

Over the years due to continuous habitation of Thessaloniki city, the hydrographic networks crossing the new city are diverted, embankmented and undergrounded. At 1958 at the upper east part of the city the peripheral drainage channel (Sotiriadis, 2002) of Thessaloniki was constructed. This channel drained the stream waters, which flooded the new urban area, growth at early $20^{\text {th }}$ century, and conducted outer of the new city. The covered torrents turned in to roads and parks. Borehole records from linear and parallel to shoreline projects, gave new evidence from streams without surface outcrop. With the aim of this methodology, the older streams before the inhabitation, the anaglyph and the shoreline were designed. In figure 2, maps of eight (8) streams were drawn with the correspondence hydrological basins (Zervopoulou, 2010). The original without interpolation stream embankments gives information about the geology and the faults, since the water follows existing structures.
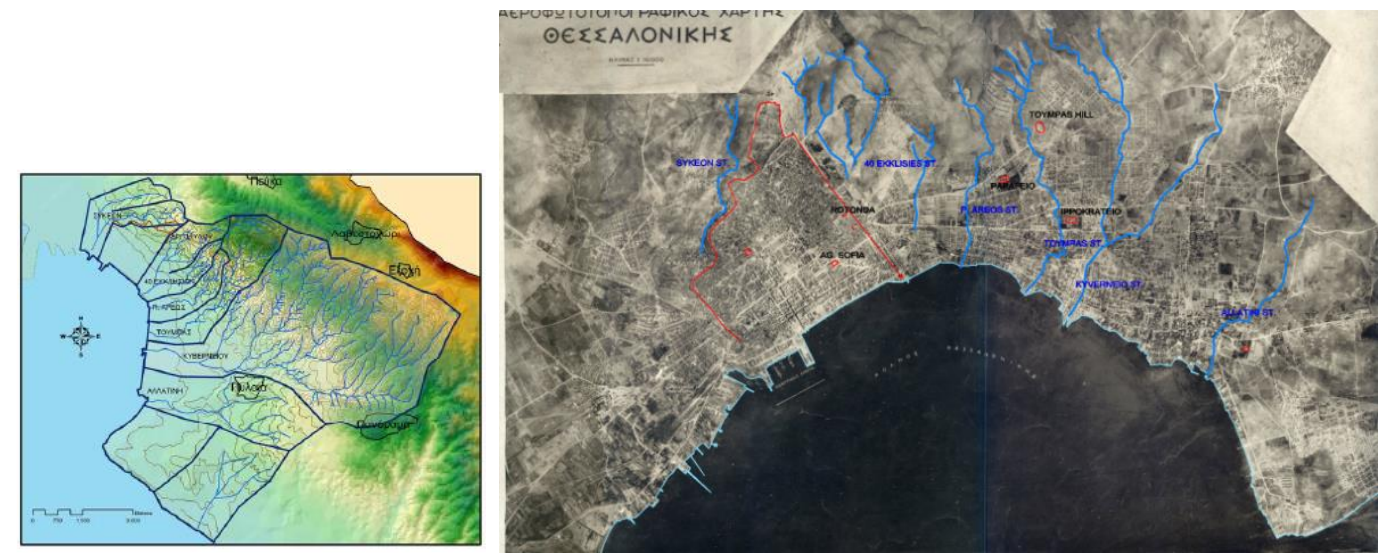

Figure 2 - Aerial photograph of 1939, with the water lines (Zervopoulou, 2010).

\subsection{Geology}

For the geological mapping in an urban area the collection and combination of many data is required. We started from geological and geotechnical maps. These maps are enhanced with excavation and borehole data. We collected more than 1500 borehole records from many projects, private and public. The main volume of data came from the Thessaloniki subway (Metro) construction (Zervopoulou, 2010). These are the most exploitable data because the borehole records are detailed and have a linear dense extend. All borehole data are evaluated and "cleaned", to minimize the number of errors that affect the quality of data (Dong et al., 2015). Finally, we created a database with elements of coordinates, elevation, project and use and depth, besides the geological and geotechnical data.

From this procedure, we had difficulties to the classification of geological deposits, because of erroneous coordinates and drilling altitude or orientation with old street names. We found borehole records from very old projects (such as a Bank building from 1926). At these records we found only geotechnical description and no geological. For example in geological description, the color of a formation is a key factor separating the Neogene formations. Also in water well records, we have not at all geological description, but only the recording of rocky basement. The absence of an organized public database of the borehole records means that, there are areas with missing geological data or borehole records that are also missing.

Finally, we organized the borehole data in 6 main geological units of Thessaloniki (Zervopoulou, 2010). Those units shown in Figure 3 are: a) at the surface the archaeological or historical layer 
(FILL) that contains human (man made) deposits with rubbles from the demolition of old constructions (Makedon et al., 2009) such as bricks, ceramics, tales, wood etc. in sands, clays, gravels and cobbles. Also contains organics and burn traces. Deeper we found b) the black organic clay with sand, extended parallel to the present seafront. This formation has low geotechnical parameters and contains also sea fossils (Vouvalidis et al., 2005) and bones.

At c) Quaternary layers, we found at the west part of the city the riverine- torrential deposits with cobbles, gravels and sands. At the east part of Thessaloniki, we have a marsh - marine or fluvial deltaic deposit that contains mostly silt and clay. At the inner city, the deposits are terrestrial and mixed up with the weathered layer of the Red Clay Series.

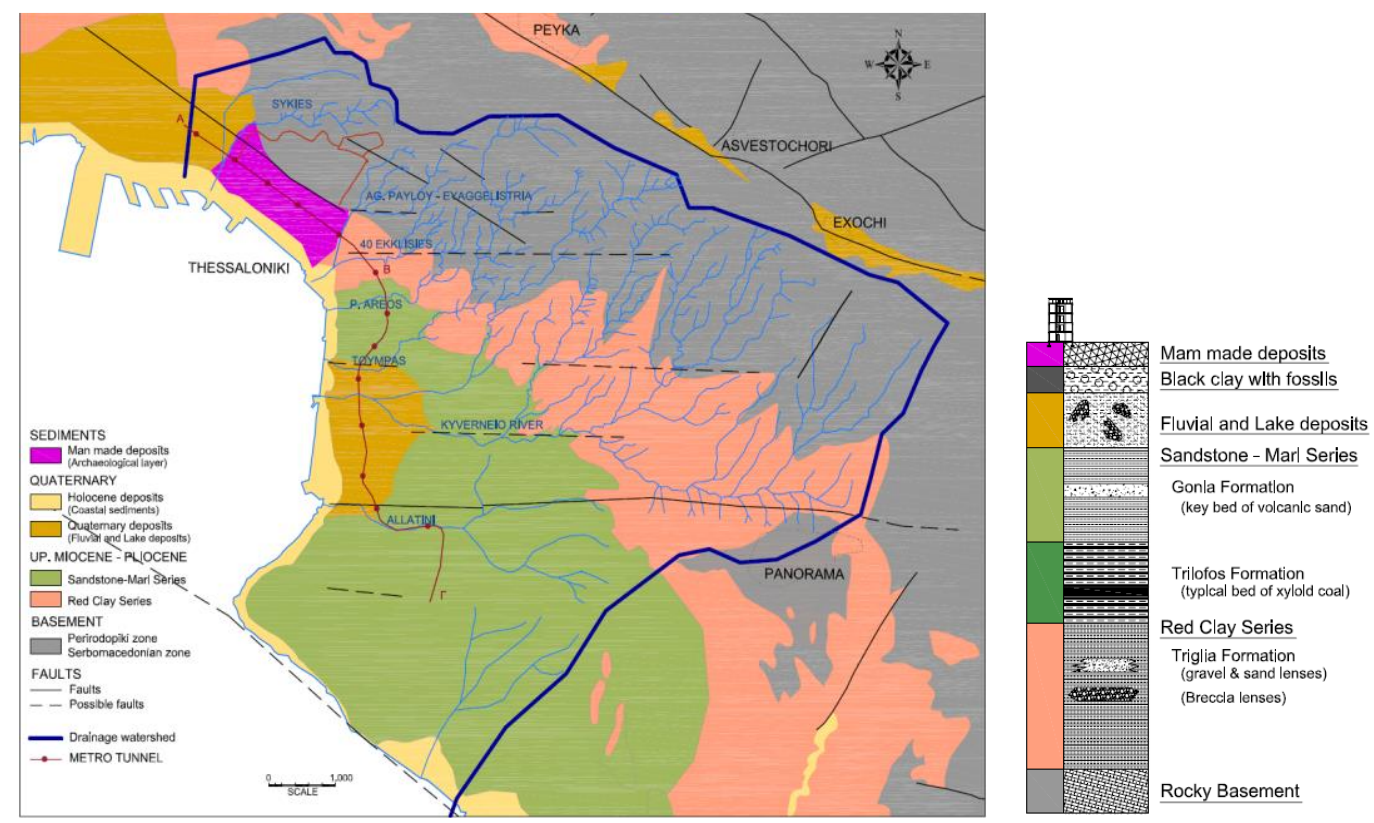

Figure 3 - Geological map of Thessaloniki city and typical geological column (Zervopoulou, 2010).

At the Neogene layers, we found first the d) Sandstone - Marl Series with alternation of dense light color sands to sandstones to very stiff calcerous clay - marls that represent a shallow brackish marine - lacustrine environment. Deeper we found e) the Red Clay Series, that consists of brown - reddish stiff to hard clays with lenses of sands and breccias. Finally, the rocky bedrock of Thessaloniki found at the surface in the low hilly part of the city, consists of Thessaloniki Greenshists of CircumRhodope zone. 


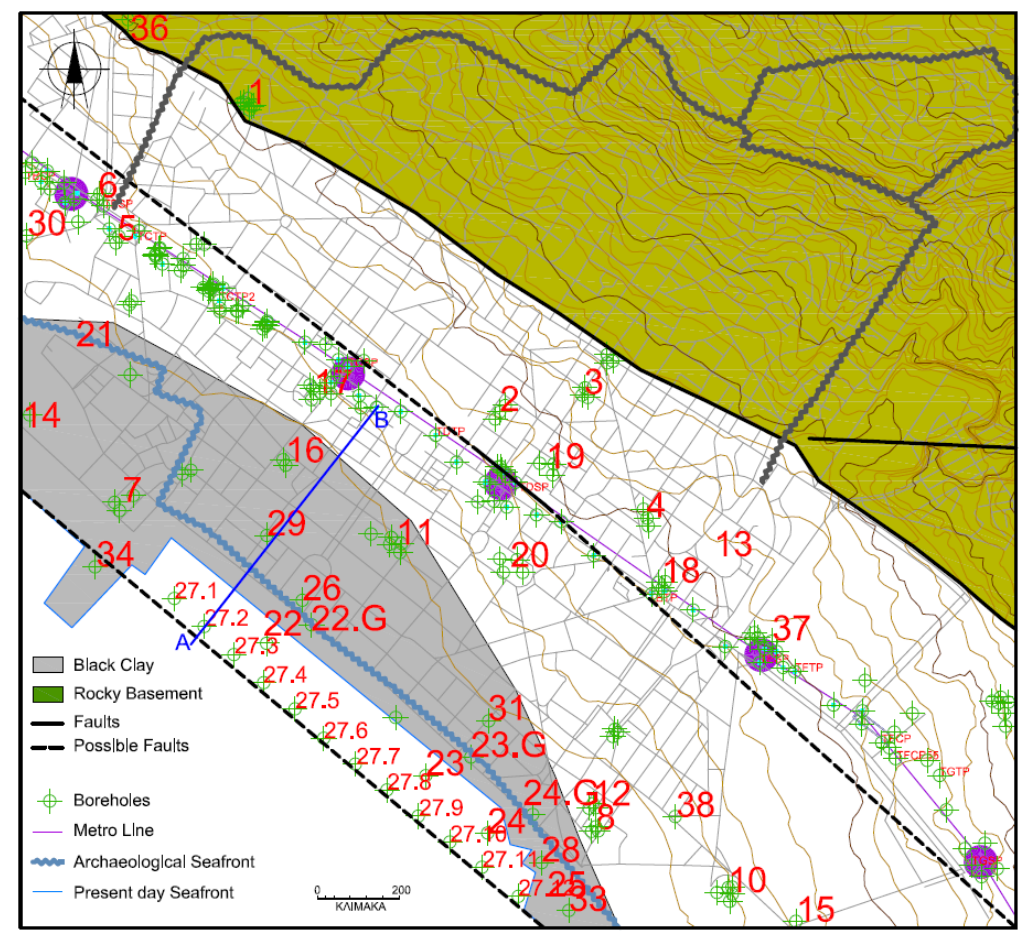

Figure 4 - Synthetic map of the inner city of Thessaloniki. The boreholes with numbers, the $t$ wo geological units of black clay and rocky basement, and the faults of Ag. Dimitriou and Eg natia streets are illustrated.

This paper focused at the inner city of Thessaloniki for the 3D modeling of geology. The inner city is the older part of Thessaloniki city with continuous inhabitation since 315BC, surrounded from the Byzantine Wall fortification. For a more detailed study the best 200 boreholes and grouped in areas were selected (Figure 4).

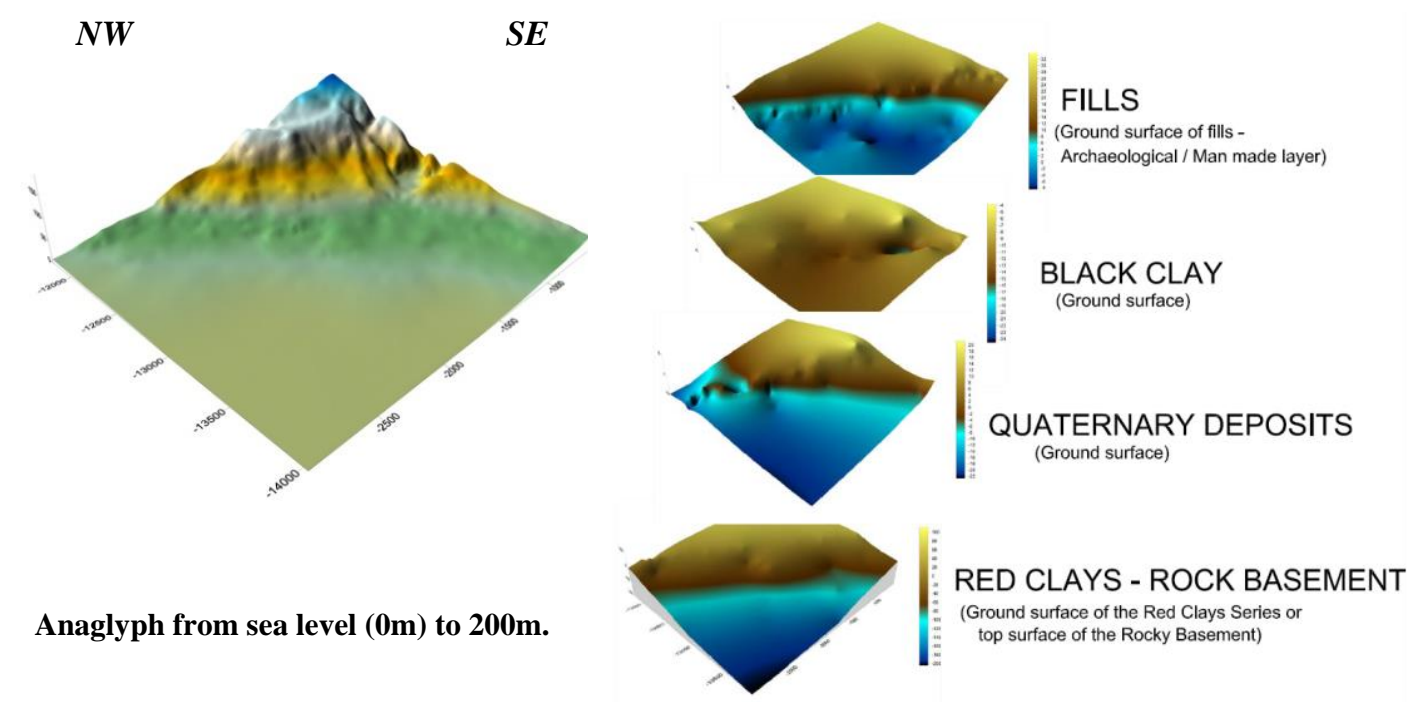

Figure 5 - Topographic ground surface map (TIN) in the inner city of Thessaloniki and the 3 D Models of the major geological units. The layers present the bottom limit of the formations. 

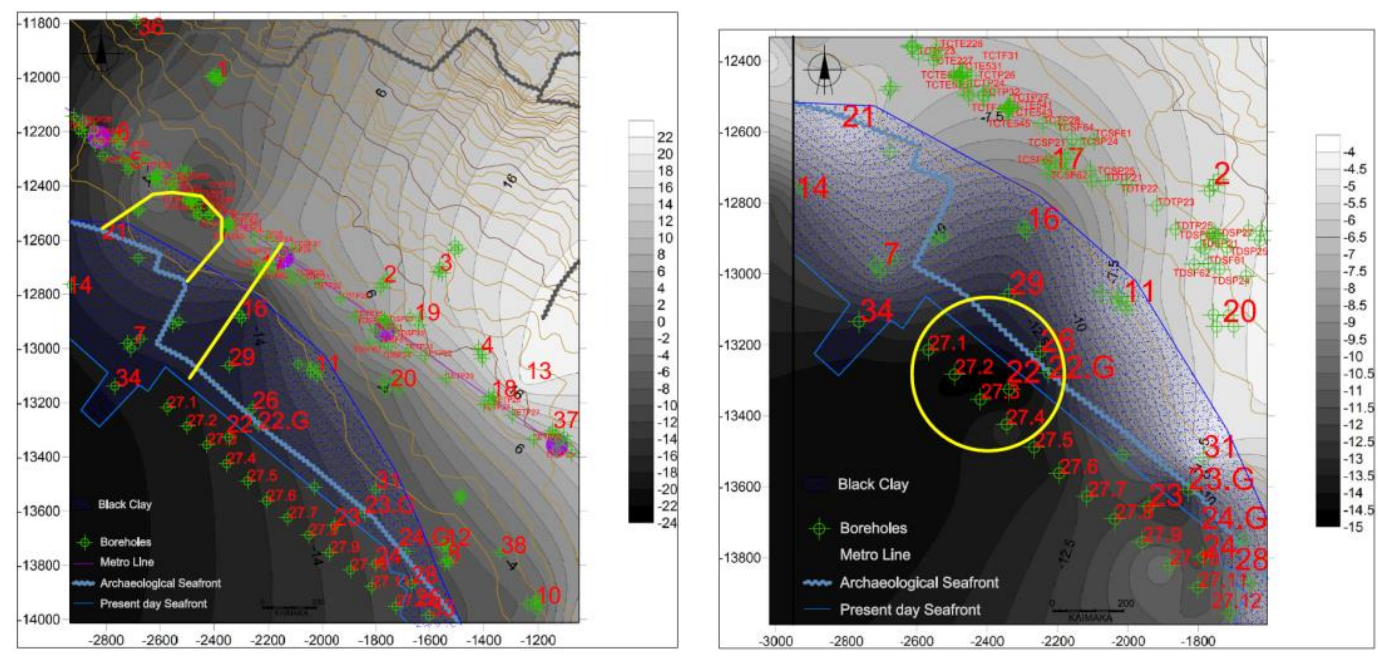

Figure 5a - The layers of Quaternary deposits and Black clay under the topographic map of the inner city of Thessaloniki.

On the first produced geological map it was distinguished the topography of the center of Thessaloniki as it was mapped from aerial photographs of 1945. The lower part shown (Figure 5) at the north east is the old Quarry of Evaggelistria. The city extends from north - northeast low hills up south - southwest at Thermaikos bay.

The mapped layer of black clay shows the change of the shifted shoreline (Vouvalidis et al., 2005). The shoreline shows a horizontal extension of 450 meters from the present artificial seaward. The historic center that is the southern Byzantine city (the fortification Walls demolished at 1866), was built 70 meters from the present seaward line. The Figure 5a (yellow circle) shows the increased depth of the layer of black clay at Aristotelous square area.

The thickness of the fill deposits in Figure 5 have been calculated, and can reach the depth of $12.6 \mathrm{~m}$ from the present ground surface (in Venizelou and Egnatia streets). These urban fill (historic deposits) have very heterogeneous thickness and composition in the center of Thessaloniki since they contains antique streets and buildings, old construction foundations, as well as antique tunnels and wells. All those betray very heterogeneous geotechnical characteristics to layer.

At the layer of quaternary deposits (Figure 5 and $5 \mathrm{a}$ ) appear a deeper line perpendicular to shoreline and another area over the old Roman - Byzantine Harbor (yellow lines). The first one we assume that is along Antigonidon Street, an (hydrographic) streamline.

On a deeper level of the 3D model, we can see the rocky basement of Thessaloniki. At the north low hill part, the basement appears on the ground surface while after Ag. Dimitriou Street, parallel normal faults lower it down to southwest over 400 meters under the present surface at seafront. The depth of 400 meters measured with the aid of geophysical investigations vertically to the shoreline (Anastasiadis et al., 2001). At the inner city, a normal fault parallel to the fault of Ag. Dimitriou identified by borehole investigations on the Egnatia Street. While parallel possible faults have also drawn, which degrade the alpine basement of Thessaloniki towards the sea (Figure 4).

In Figure 6 a characteristic geological column of the layers under the topsoil in the center of Thessaloniki is demonstrated. Similarly, the next cross section shows the development of the geological layers perpendicular to the coastline in the area of Aristotelous Square. 

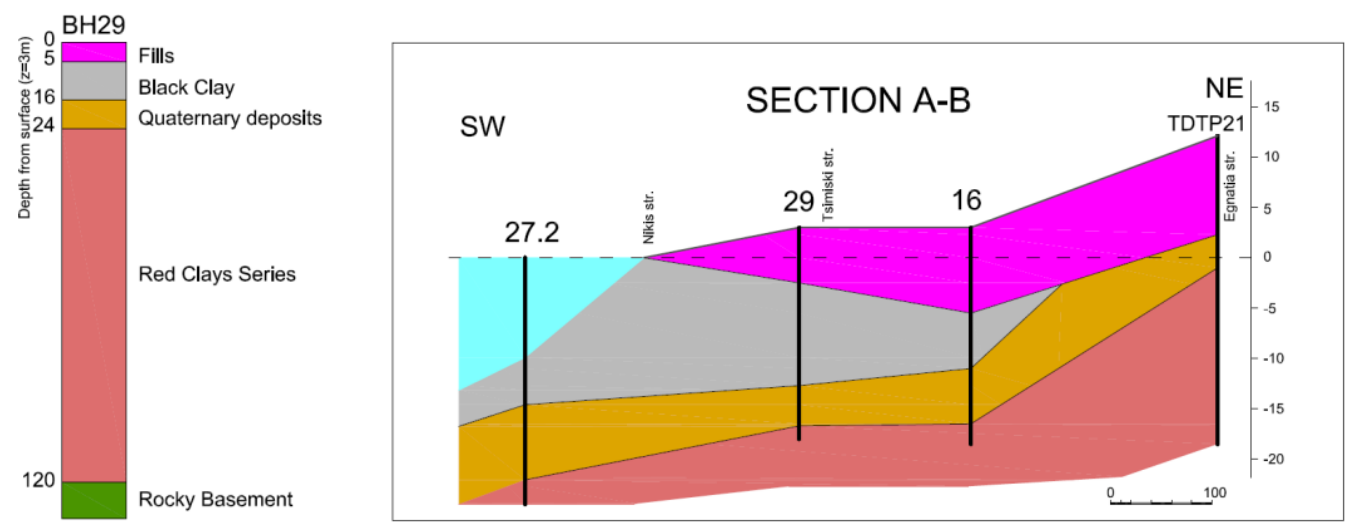

Figure 6 - Geological column of the inner city of Thessaloniki at Tsimiski street and A-B geological section from Fig.4 map.

\subsection{Structural geology}

The study of the geology of the city of Thessaloniki involves information about the tectonics regime. They identified the older faults, which gave the initial configuration of the city. These faults extend NW-SE, were activated at Pleiocene - L. Pleistocene and they are mainly located in contact with the bedrock (Ag. Dimitriou Fault). More important in this paper are the neotectonic faults with E-W direction. These faults have been found to affect the recent sediments in the eastern area of the city (Zervopoulou, 2010). Older mappings of fault structures were up to the limits of built-up areas (Tranos et al., 2003). Using this methodology, we found that they extended in the modern city area, like Pylea - Panorama Fault at Voulgari Street.

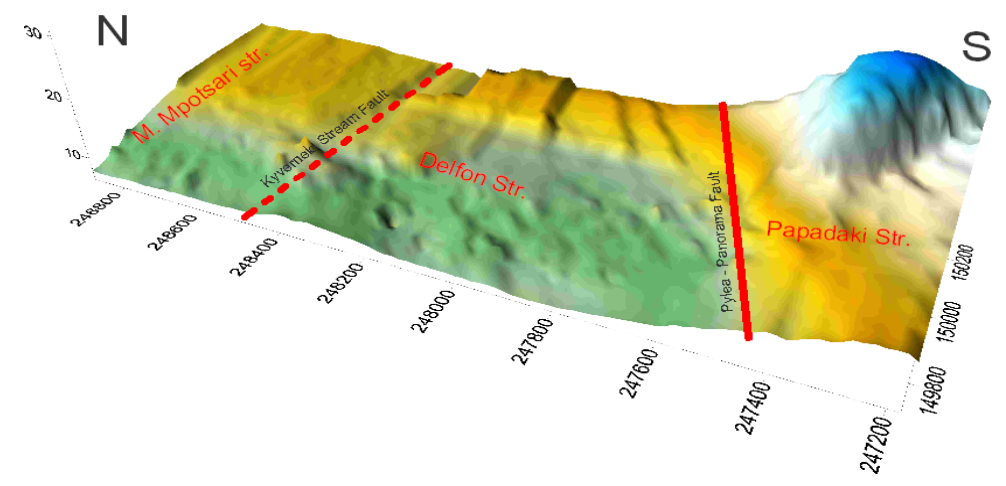

Figure 7 - 3D model of the east part of Thessaloniki, shown the graben between the two faults of Kyverneio and Pylaia - Panorama (Zervopoulou, 2010).

Apart from the cracks in the center of Thessaloniki, in the city's eastern region identified normal faults parallel in the streams Pediou Areos and Kyverneiou, as well as identified the Pylea Panorama fault (Zervopoulou, 2010). These faults reveal the structure of the city at the east and create a lower-lying area, where most streams flowing (Zervopoulou et al., 2014). Finally, in a recent excavation for building construction, the Kalamaria normal fault was found (Zervopoulou, 2010).

The Pylea - Panorama fault is the most important fault crossing the eastern city of Thessaloniki. It trends W-E, dips to the north and has maximum displacement more than 40 meters at Voulgari area across the homonym street. The fault is about $12 \mathrm{~km}$ long and characterized as active fault (Zervopoulou, 2010). The eastern part of the fault follows the Kyvernio streamline and shifts the 
Elaiorema stream brunch at Panorama area. The western part of the fault extends parallel to Allatini streamline.

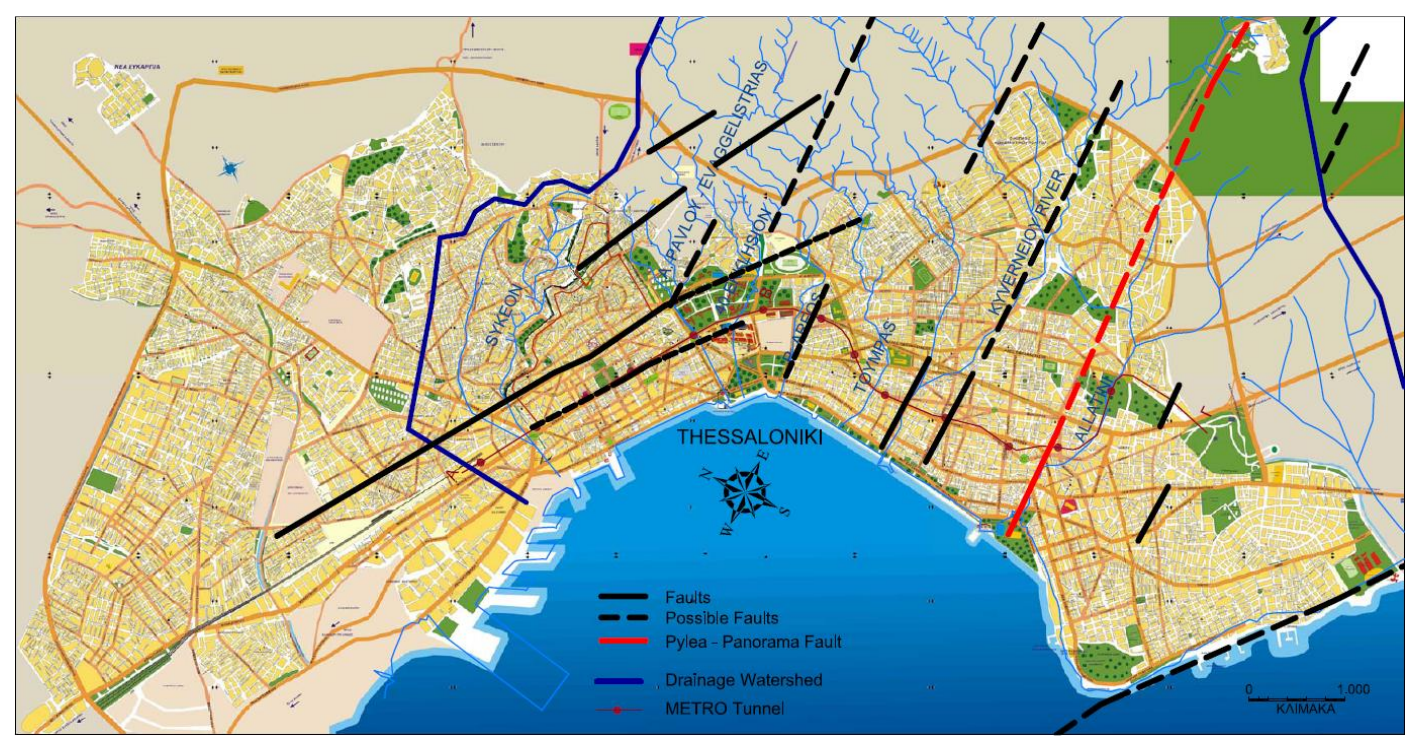

Figure 8 - Tectonic map of the urban area of Thessaloniki (Zervopoulou, 2010).

\section{Conclusions}

Active faults across urban area are great potential threats. Their activity may cause severe damage to lifelines, critical facilities and local utility distribution systems. Most urban active faults become concealed faults with unknown trace, usually covert by quaternary unconsolidated sediments or they have disappeared their morphological traces.

At these paper the geology of the city of Thessaloniki and in particular the area of the inner city (historic center) mainly was studied. Data such as borehole records, geophysical and excavation profiles have been used and assessed in combination with geological maps, topographic and archival publications led to the production of new thematic maps. In these thematic maps, shown in 3D models, the geology of the area below the build surface and the tectonics is illustrated. So identified faults hidden inactive and active/possible active. These 3D models, with further research, could assist to the production of thematic hazard maps and seismic risk maps.

This methodology describes a detailed recording of geology in depth under a constructed area and thus the tectonic regime, while identifies areas that can present certain geotechnical problems. The natures of these problems are the potential liquefaction in areas with silty and sandy subsoil as well as in coastal black clay. Settlements at buildings founded in loose and heterogeneous soils such as the human fills (anthropogenic layers) in the center of Thessaloniki. But also, differing settlement on both sides of a fault, such as in Pylea - Panorama fault. At rocky faces appeared slope stability problems, such as in the Upper (old) city of Thessaloniki.

\section{Acknowledgments}

The authors would like to thank Attiko Metro S.A. and J/V A.I.S. (AEГEK - IMPREGILO - SELI) for providing the boreholes data from the Thessaloniki Metro construction. The authors would like also to express their sincere thanks to ITSAK, IGME and colleagues geologists for providing useful boreholes data. 


\section{References}

Alfors, J.T., Burnett, J.L. and Gay, T.E., 1973. Urban geology masterplan for California. The nature magnitude and costs of geologic hazards in California and recommendation for their mitigation, California Div. of Mines and Geology, Bull., 198 pp.

Anastasiadis, A, Raptakis, D. and Pitilakis, K., 2001. Thessaloniki's Detailed Microzoning: Subsurface Structure as Basis for Site Response Analysis, Pure and Applied Geophysics, 158 , 2597-2633.

Chuang, X., Hai-hong, W., Zhi-cai, L., Jin-sheng, N. and Hua-liang, L., 2015. Multilayer stress from gravity and its tectonic implications in urban active fault zone: A case study in Shenzhen, South China, J. of Applied Geophysics, 114, 174-182.

Culshaw, M.G. and Price, S.J., 2011. The 2010 Hans Cloos lecture, Bulletin of Engineering Geology and the Environment, 70(3), 333-376.

Legget, R.F., 1973. Cities and Geology, McGraw-Hill, N. York, 654 pp.

Makedon, T., Chatzigogos, N.P. and Spandos, S., 2009. Engineering geological parameters affecting the response of Thessaloniki's urban fill to a major seismic event, Engineering Geology, 104, 167-180.

McCall, G.J.H., De Mulder, E.F.J. and Marker, B.R., 1996. Urban Geoscience, A.A. Balkema, Rotterdam.

Marinos, G.P., 2001. Engineering geology, A.A. Balkema, Rotterdam. ISBN 905410631.

Dong, M., Neukum, C., Hu, H. and Azzam, R., 2015. Real 3D geotechnical modeling in engineering geology: a case study from the inner city of Aachen, Germany, Bulletin of Engineering Geology and the Environment, 74(2), 281-300.

Pavlides, S.B., Caputo R. and Chatzipetros, A., 2000. Empirical relationships among earthquake magnitude, surface ruptures and maximum displacement in the broader Aegean Region, Proceedings of the 3rd International Conference on the Geology of the Eastern Mediterranean. In: Panayides, I., Xenophontos, C. and Malpas, J., eds., 159-168.

Sextos, A. and Stylianidis, K., 2007, Seismic performance of the 4th century A.D., Byzantine land walls of the city of Thessaloniki, Greece, 4th International Conference on Earthquake Geotechnical Engineering, Thessaloniki, Paper W2-1008.

Tranos, M.D., Papadimitriou, E.E. and Kilias, A.A., 2003. Thessaloniki-Gerakarou fault zone TGFZ: the western extension of the 1978 Thessaloniki earthquake fault northern Greece and seismic hazard assessment, Journal of Structural Geology, 25, 2109-2123.

Tsotsos, S., Hatzigogos, T., Manou-Andreadis, N., Theoharidou, K. and Xanthos, V., 1988. Geotechnical problems of the foundations of Byzantine and post Byzantine monuments in Thessaloniki, Greece, Engineering Geology of Ancient Works, Monuments and Historical Sites, 1, 487-494.

Vouvalidis, K.G., Syrides, G.E. and Albanakis, K.S., 2005. Holocene morphology of the Thessaloniki Bay: impact of sea level rise, Zeitschrift für Geomorphologie, 137, 147-158.

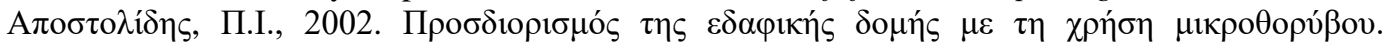

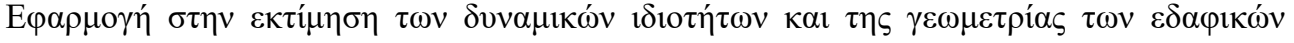

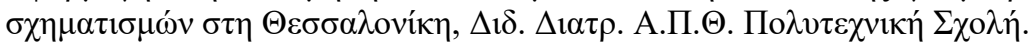

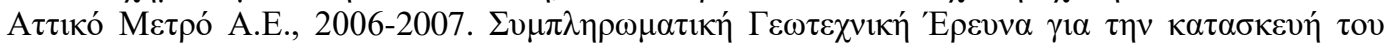

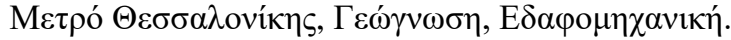

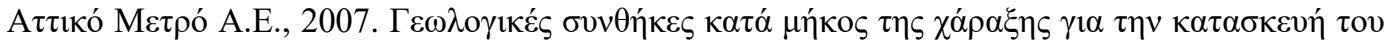

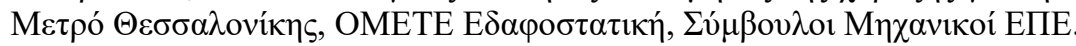

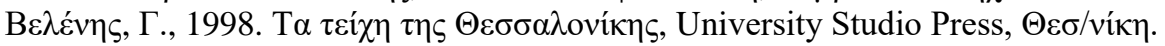

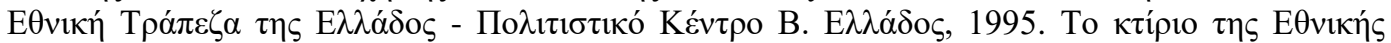

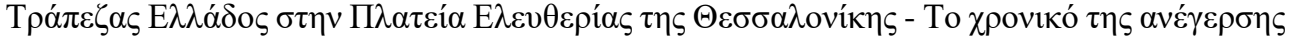

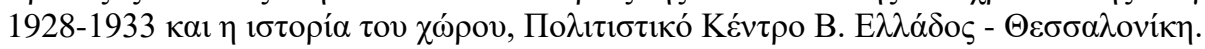

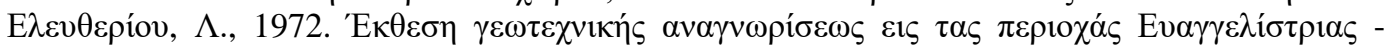

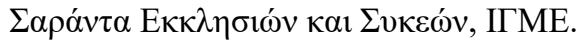




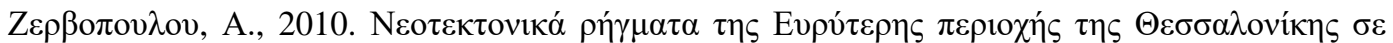

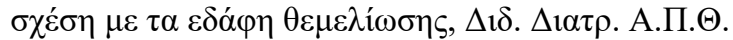

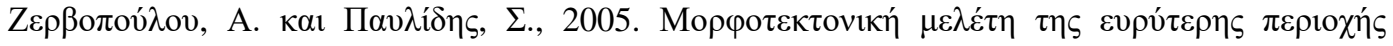

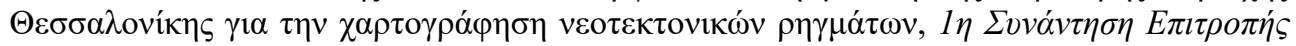

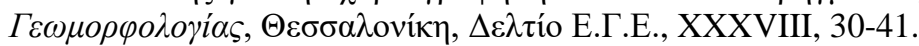

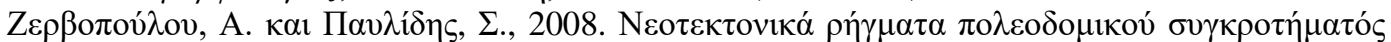

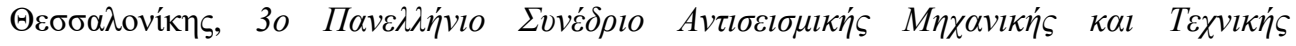

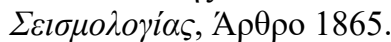

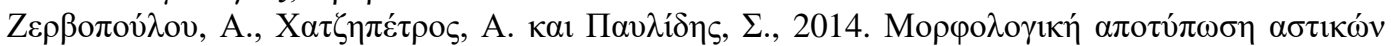

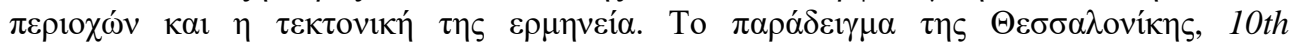
International Congress of the Hellenic Geographical Society, 166-168.

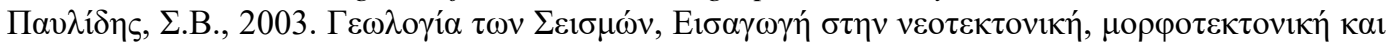

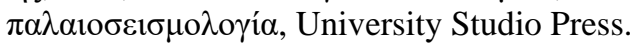

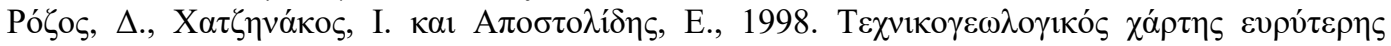

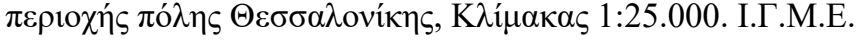

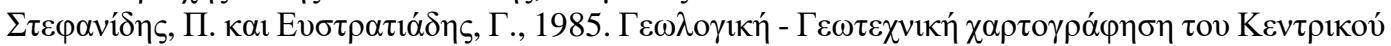

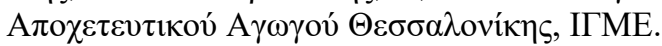

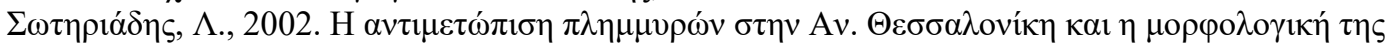

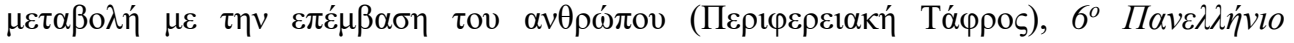

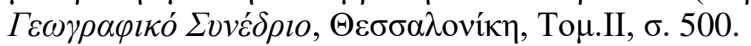

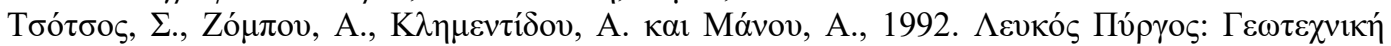

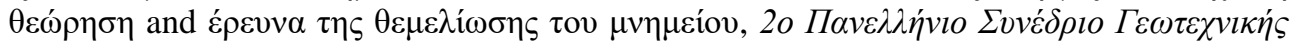

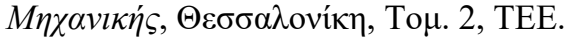

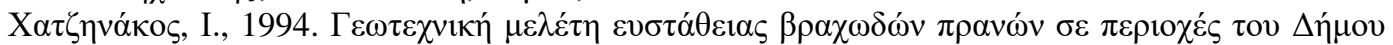

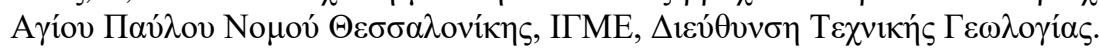

